\title{
Green energy from a hybrid PV panels and wind turbine farm in Lebanon
}

\author{
Bassel I. Nesser, Mohamed Hassan Soliman \\ VSB-Technical University of Ostrava, Czech Republic \\ Krzysztof Pytel \\ AGH University of Science and Technology, Poland
}

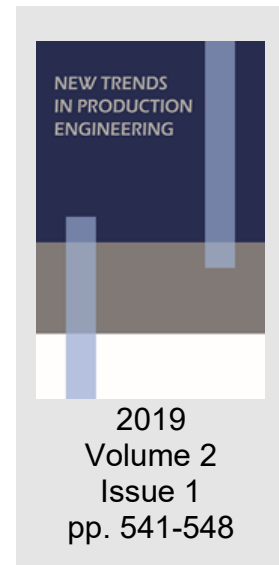

Date of submission to the Editor: 05/2019

Date of acceptance by the Editor: 08/2019

\section{INTRODUCTION}

Energy has become the most wanted and desirable power to control, produce and manage. In the engineering world, the production of power means high quality with low cost and that is what reflects how much sophisticated the country is. The world started centuries before to find a replacement for the fuel-based power production. Unfortunately, Lebanon is facing hard problems when it comes to satisfy the demands of electricity especially with the actual overload in population. Science development has reached to create electrical power by investing the sun light through photovoltaic panels and the wind velocity through wind turbines. Photovoltaic panels are made of semiconducting materials similar to those used in computer chips. When sunlight is absorbed by these materials, the solar energy knocks electrons loose from their atoms, allowing the electrons to flow through the material to produce electricity. This process of converting light (photons) to electricity (voltage) is called the photovoltaic (PV) effect (Renewable Energy World, 2016).

Day after day, this technology has become one of the simplest and effective tools since it is seen in many applications in our own lives as calculators, watches, space applications, energy production.

Projects concerning power production are being developed in Morocco under the name of Noor one, Noor two till Noor five since it has no fossil fuel reserves where the last project will be built by the king in 2018 with photovoltaic system and concentrated solar power (CSP) to add to the national power production two $400 \mathrm{MW}$ from the combined system (The Guardian, 2016).

Photovoltaic panels can be categorized in three types, first comes the traditional solar cell made from silicon, they are usually flat plates and they are affected by the cloudiness, sun position and the angle that the sun light hits it, more the sun light becomes normal more efficient it is. Then, comes the second-generation solar cells called thin-film solar cells made from amorphous silicon and non- 
silicon materials. And finally, the third-generation solar cells where we have a combination of plates made of amorphous silicon and conductive materials.

In the other hand, wind energy technology became essential in the green energy production especially in Canada, USA, and Europe etc. It is highly used in Canada since 2000 where a set of $10 \mathrm{GW}$ wind energy is installed while in the other hand, there was only $137 \mathrm{MW}$ of installed capacity operating around the world. By further use of this power production technology, Canada can later generate 100 per cent of electricity from zero emission generation sources (CanWEA, 2010).

Mainly, two types of wind turbines exist: the horizontal axis wind turbine which is the most commonly used type around the world; its main rotor shaft is placed horizontally on the top of the holding axis while in the vertical axis wind turbine, the rotor shaft is vertical and the gearbox can be securely placed on ground.

\section{METHODOLOGY OF RESEARCH}

In this publication, a genuine system combining the wind and photovoltaic energy is being designed, taking advantage of the zero cost of the land at the middle of the coastal highway and the proximity of the system to the utility grid. The total land measured is 27800 meters reduced to 27300 meters by removing all obstacles that can intercept the installation of the system like bridges, publicity panels, steel borders etc. The system will be designed upon the thirdgeneration solar cells for their effectiveness and the vertical axis wind turbines for safety and stability reasons. Also, the advantages of this combination is that at least one of the system at a certain time is generating power, for example, at night the vertical axis wind turbines will be producing power while photovoltaic panels are zero effective and during the day, both systems are generating the power unless wind velocity is incapable of turning blades. This paper is set to design this combined system and calculate how much power can be generated taking into consideration the average coastal wind speed and the annual average power produced by photovoltaic panels. In addition, on the financial level, a study will be made to show how much this project is a money-saving by avoiding the application of the storage system and by installing the system on free land.

The purpose of the work is to select the elements of the energy system. The climatic conditions have first been studied and the maximum wind speeds that can affect the strength of structures for wind power plants and solar panels have been determined. The second step of the analysis was to verify the strength of materials system. In the next stage, the obtained power was analysed and related to the project costs. An extremely important element of the investment is the impact on the environment, which in the case of a large number of constructions may turn out to be negative. Based on the obtained information, guidelines for further analysis were developed. 


\section{RESULTS OF RESEARCH}

The objective of design part is analysis of climatic conditions and selection of appropriate elements of the power production system. The modelling part is about collecting the data related to the wind speed at the coastal Lebanese highway in a certain range of time and during many days in order to estimate an average value of the wind speed to finally calculate the electrical energy produced by this value. Over almost a month, wind speed was measured in a spot near Adloun using a flowmeter from $3 \mathrm{~m}$ above the highway where the air will be more uniform to present later accurate calculations and results. The Fig. 1 shows some of the results measured from 29 March until 15 April, from 12 noon until 19:00.

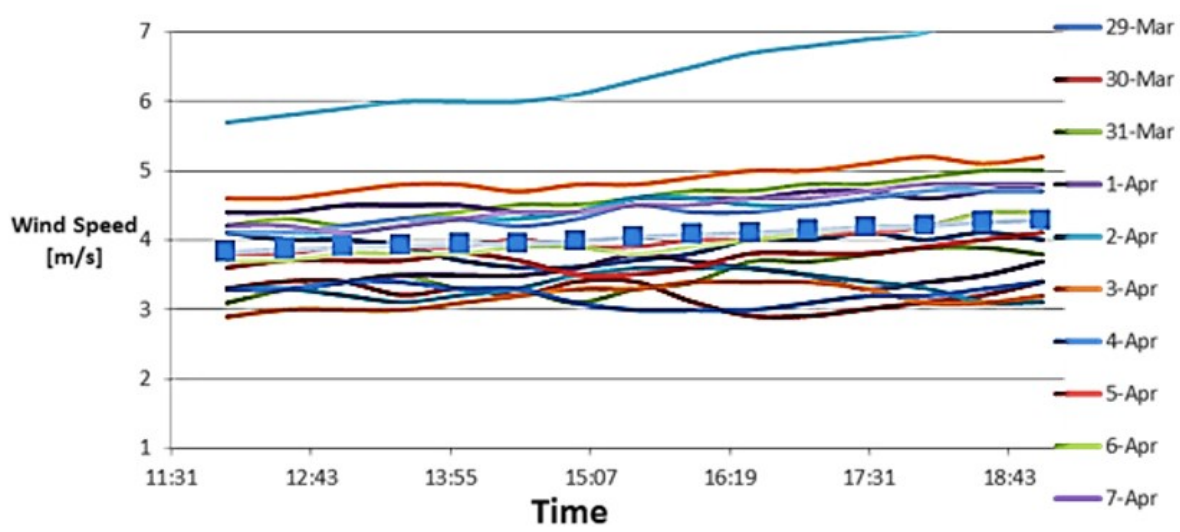

Fig. 1 Visual information about some of the results of wind speed measurements from 29 March till 15 April, from 12 noon till 19:00

The full data gave us $4.04 \mathrm{~m} / \mathrm{s}$ as an average wind speed in the area of measurement located in the coastal highway considered as an effective value in the wind power production.

The 300 watts polycrystalline panels will be chosen for the installation of the system since it has the higher power rate among all the photovoltaic panels exposed in the Lebanese market with the vertical axis wind turbine to form a combined green energy power production system.

As for the turbines, each turbine will be designed as the Savonius type having a height of 1 meter and a radius of 0.5 meter made from composites material known with their high strength to weight ratio. The vertical axis wind turbines will be running $3 \mathrm{~m}$ above the steel chassis for drivers safety and to be in the uniform wind speed space with air density of $1.2 \mathrm{~kg} / \mathrm{m}^{3}$, where $0.9 \mathrm{~m}$ stands between each turbine with each two pairs of panels avoiding by this design any type of shadow effect on the panels that might make the system incapable of producing power.

The photovoltaic panels will count 15222 placed on steel chassis along the entire 27300 meters coastal distance and 2 meters wide where 7610 vertical axis wind turbines will be placed in between each two consecutive pairs of photovoltaic panels at a distance of $0.9 \mathrm{~m}$ in between. 


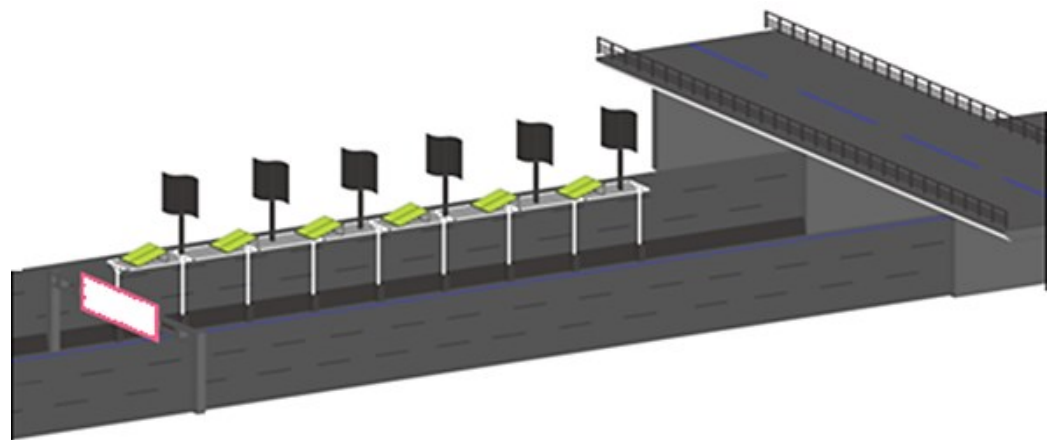

Fig. 2 A general view of the combined system

The steel chassis consists of many types of geometries such as a hollow square, angle $L$ bar, connecting fixture etc. (Table 1 ). They are galvanized in order to resist corrosion bending and any type of defect. The photovoltaic panels placed on the steel chassis will be inclined by $24^{\circ}$ due south for their optimal power production at such angle at the coastal area (Wholesale solar, 2019).

Table 1 Shapes, quantity, names and cost of the power production system

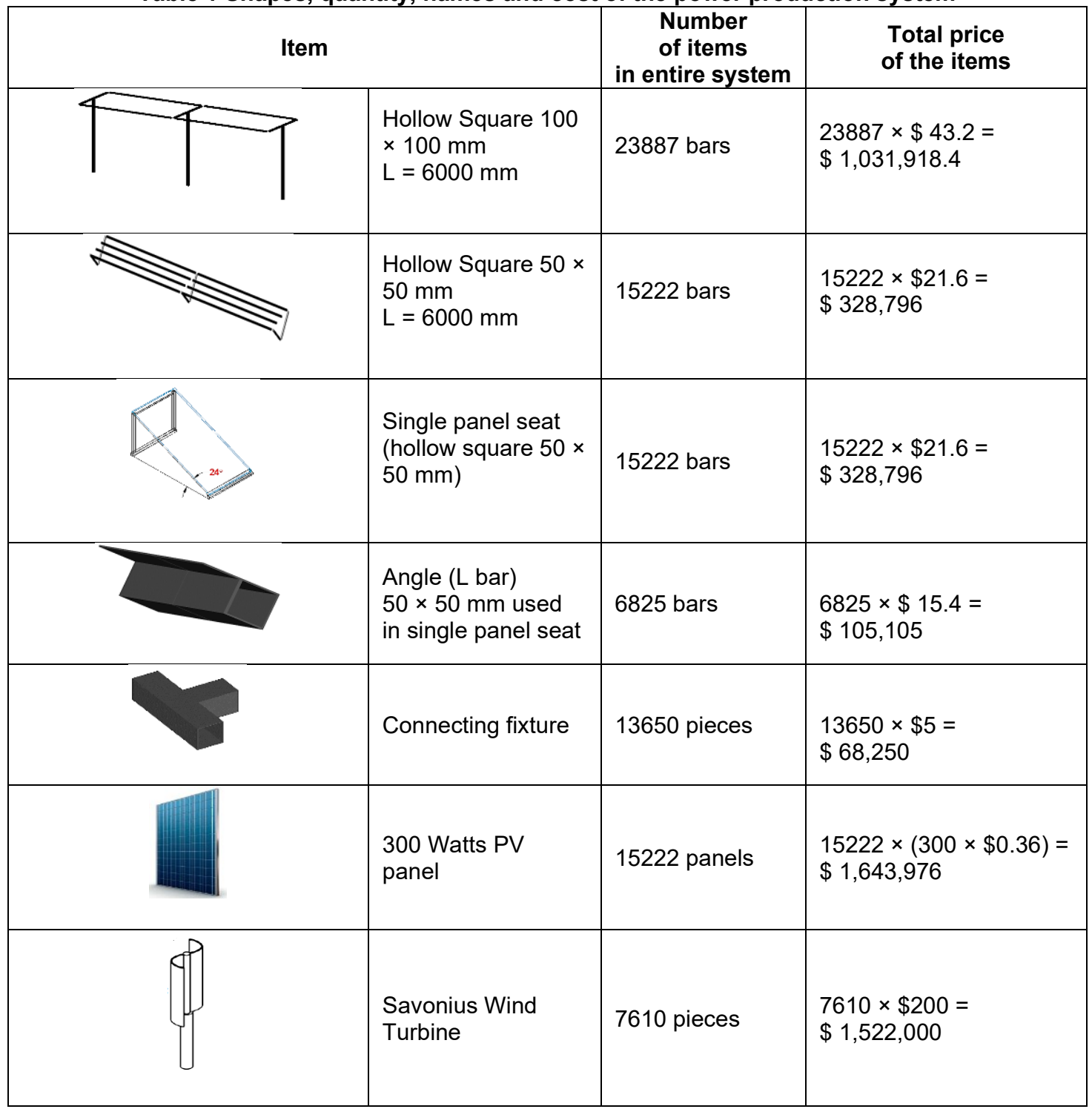


The objective of structural analysis is to study the materials strength at a wind speed of $120 \mathrm{~km} / \mathrm{h}$ and its effect on steel chassis with PV panel (Fig 3-4).

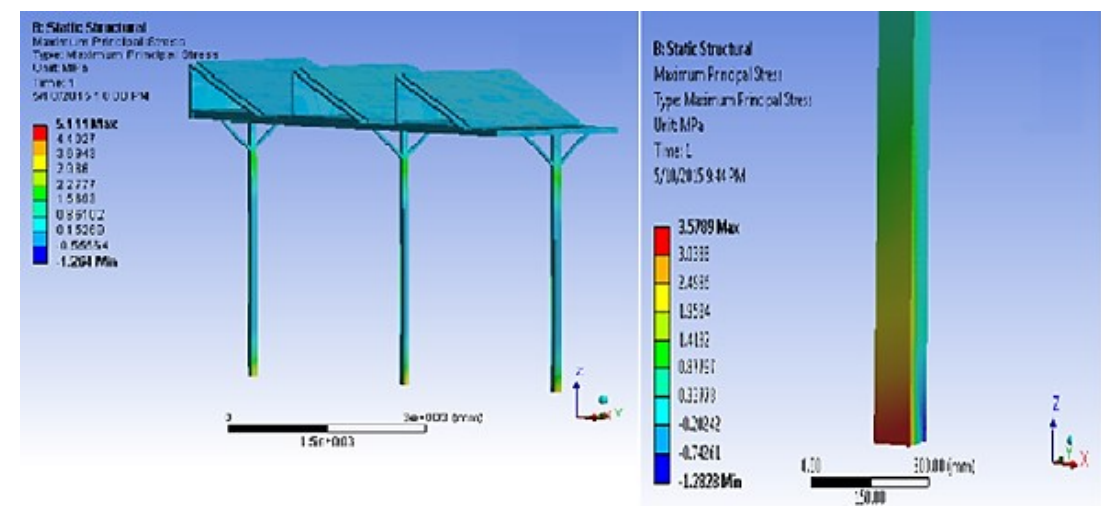

Fig. 3 A maximum principal stress at $120 \mathrm{~km} / \mathrm{h}$ (Frontal and side impact) on steel chassis with PV panel

The maximum principle stress made by wind impact is $5.11 \mathrm{MPa}$ is way far from the steel yielding strength (250 MPa) which makes the steel chassis in the safe zone with a safety factor of almost 50 (Fig. 4). As for the turbines, simulation of the pressure made by the wind on the turbine blades was performed.
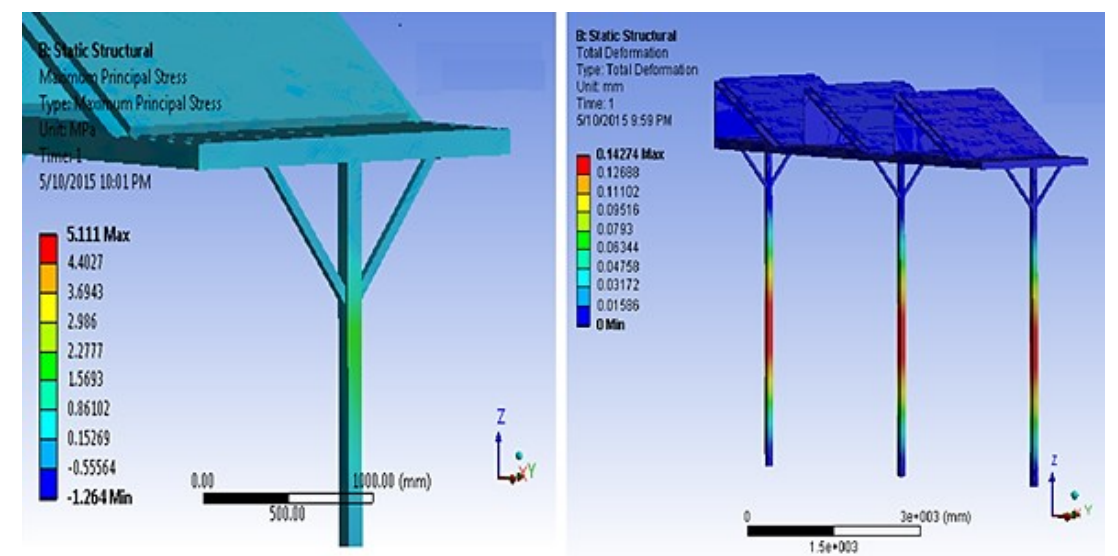

Fig. 4 A maximum principal stress and deformation at $120 \mathrm{~km} / \mathrm{h}$

A wind velocity of $12 \mathrm{~m} / \mathrm{s}$ that is rarely to happen in Lebanon is taken to study the materials strength against it. The maximum pressure made on the blades is $1.09 \mathrm{kPa}$ which is also very low with respect to blades yielding strength (240 $\mathrm{MPa}$ ) making the system in the total safe zone against yielding (Fig. 5).

The objective of a power calculation and project costs is analysis of a total annual average power generated by the PV panels and Savonius wind turbines. The nominal peak power generated by each photovoltaic panel is 300 watts which makes 4.6 MW of the total nominal power generated by 15222 items of 300 Watt devices. The annual average power that can each photovoltaic panel generate is $486 \mathrm{KWh} / \mathrm{y}$, which makes the total annual average energy generated by the panels equals $7.4 \mathrm{GWh} / \mathrm{y}$. The vertical axis wind turbines system at the average wind speed at the coastal highway area of $4.04 \mathrm{~m} / \mathrm{s}$ generate the maximum power by each one in about $46.89 \mathrm{~W}$, that is the total power generated 
by 7610 devises equals to $0.3568 \mathrm{MW}$, the annual amount of energy generated from the Savonius turbines only is $3.1 \mathrm{GWh} / \mathrm{y}$.

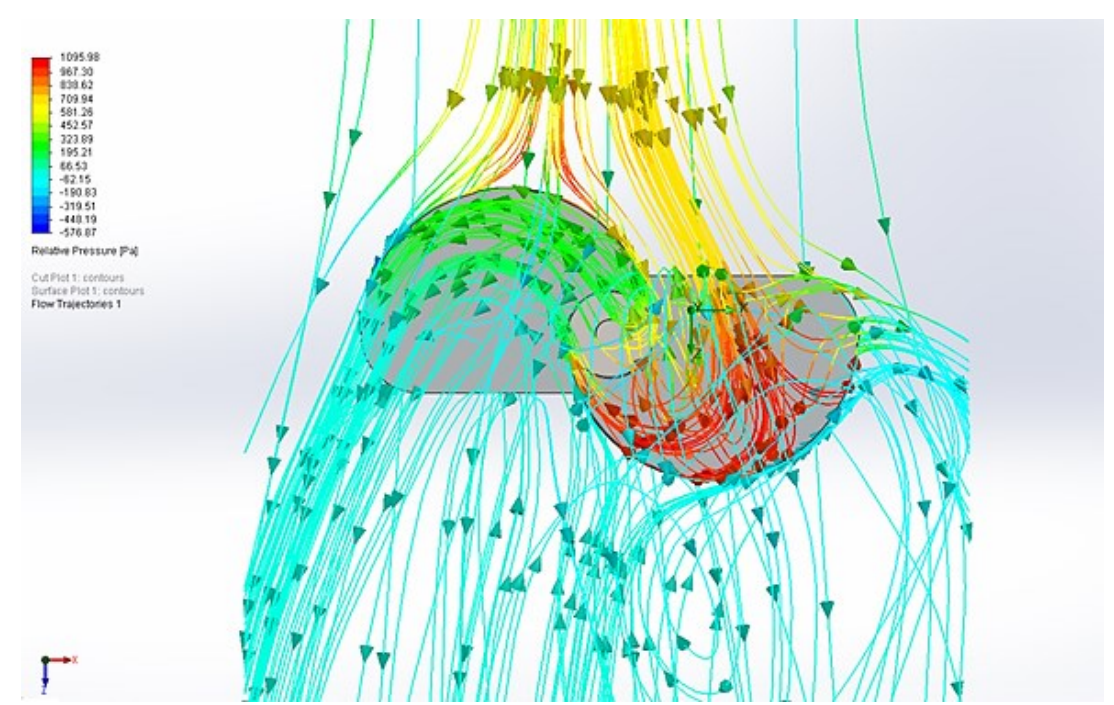

Fig. 5 A pressure made by air on turbine blade at $12 \mathrm{~m} / \mathrm{s}$

The total annual energy generated by the PV panels and the vertical axis wind turbines system equals to $10.5 \mathrm{GWh} / \mathrm{y}$. The total costs of analysed green energy system will not cross 7 million dollars taking into consideration the total costs of each item (Table 1) and the labour costs, inverter and other equipment costs. The energy production process in this proposed project is conventional, which means that no stirrer will be initiated to start the power production process. Therefore, no carbon dioxide is emitted. However, the amount of carbon dioxide released into the atmosphere has been rising highly in the last 150 years due to the last human activities such as burning fossils, producing cement, carrying out land clearing and forest combustion. Many gases including carbon dioxide are also released and are called greenhouse gases where any change in their quantities will increase earth temperature causing by that the global warming where scientists claim that catastrophic results will be produce such as melting of ice caps, increase in storm activities, flooding of inhabited continents. On the health level, carbon dioxide is very important for humans, it is a guardian of the $\mathrm{pH}$ of the blood and important in the respiration cycle (Lenntech Water treatment \& purification Holding B.V, 2009). However, the increase of the amount of carbon dioxide in the atmosphere can critically damage the existence of human beings by time, it can make kidney damage or coma and can be dangerous in the process of asphyxiation when carbon dioxide is released and can affect humans when its concentration is very high in atmosphere (U.S. Energy Information Administration, 2017).

The presented solution is environmentally friendly (Fthenakis and Alsema, 2006).

\section{CONCLUSION}

This electrical power generation project is a supporting project to the Lebanese government by creating electrical energy by installing photovoltaic panels and 
vertical axis wind turbines on steel chassis in the middle of the coastal highway from Tyre to Sidon along $27 \mathrm{~km}$. The project will inject directly the created energy into the utility grid saving by this the storage system cost. On the other hand, it is also saving the land cost since it is installed on a government land that will exceed 15 million dollars where the total project cost will not exceed 7 million dollars including the materials needed to build it and the labours cost (Gumula, S. et al., 2015).

The photovoltaic panels mounted on the steel chassis will count 15222 panels placed in pairs and away $0.9 \mathrm{~cm}$ from each vertical axis wind turbine for safety reason and to avoid any kind of shading effect, those turbines will count 7610 and will be running $3 \mathrm{~m}$ above the steel chassis.

The total annual electrical power generated from the combined system is 10.5 GWh/year. Separately, the total annual electrical power generated from the photovoltaic panels is $7.4 \mathrm{GWh} / \mathrm{y}$ and $3.1 \mathrm{GWh} / \mathrm{y}$ is the one generated from the turbines at an average wind speed of $4.04 \mathrm{~m} / \mathrm{s}$.

The proposed design is in the safe zone against any type of failure or yielding principle since the chassis and the turbines blades are made from high strength materials. In addition, the proposed project is environmentally friendly with no carbon dioxide emission where its extreme emission can lead into global warming and bad effects on humans, animals and plants ending by time the existence of life on earth.

\section{REFERENCES}

CanWEA, (2010), Available at: https://canwea.ca/wind-energy/national/ [Accessed 11 sept. 2017].

Fthenakis, V. and Alsema, E. (2006), Photovoltaics energy payback times, greenhouse gas emissions and external costs: 2004-early 2005 status, Progress in Photovoltaics, 14, pp. 275-280.

Gumula, S. Hudy, W. Piaskowska-Silarska, M. Pytel, K. (2015). The effect of greenhouse gases and natural factors on the changes in Earth temperature. Przemysł Chemiczny, 94 (9), pp. 1515-1517.

Lenntech Water treatment \& purification Holding B.V,(2009), Carbon Dioxide Available at: https://www.lenntech.com/carbon-dioxide.htm [Accessed 17 sept. 2017].

Renewable Energy World, (2016), Richard Komp, Available at: www.renewableenergyworld.com/solar-energy/tech/solarpv.html [Accessed 6 Sept. 2017].

The Guardian, (2016), Celeste Hicks, Available at: https://www.theguardian.com/global-development/2016/nov/17/cop22-hostmorocco-lights-way-africa-renewable-energy-2020 [Accessed 9 Sept. 2017].

U.S. Energy Information Administration, (2017). Available at: https://www.eia.gov/electricity/annual/html/epa_08_04.html [Accessed 13 sept. 2017].

Wholesale solar, (2019), Available at: https://www.wholesalesolar.com/solar-panels [Accessed 24 May 2019]. 


\begin{abstract}
.
The publication presents the results of analysis of green energy from a hybrid PV panels and wind turbine farm use in Lebanon. Electricity is one of the most critical problems in Lebanon. This publication presents an effective solution to this issue. It deals with the generation of green environment friendly electricity from photovoltaic (PV) panels and wind turbine. The genuine idea consists of placing these panels and turbines at the middle of the coastal highway since it is considered as a free land. The produced energy is fed directly to the off gird after being inverted using appropriate devices. The middle of the highway from Tyre to Sidon is considered to apply this research. The actual design consists of $15222 \mathrm{PV}$ panels placed in pairs on a steel chassis among the entire $27300 \mathrm{~m}$ coastal distance, 2 meters wide and 7610 vertical axis wind turbines placed at a distance of $0.9 \mathrm{~m}$ away from each pair of $\mathrm{PV}$ panels. The total energy produced by the PV system is estimated to $7.4 \mathrm{GWh} / \mathrm{y}$ and 3.1 $\mathrm{GWh} / \mathrm{y}$ at an average wind velocity of $4.04 \mathrm{~m} / \mathrm{s}$. In addition to its benefit from a free land, the produced energy is environment friendly since there is no carbon dioxide emission.
\end{abstract}

Keywords: Vertical Axis Wind Turbine, PV Panel, Carbon Dioxide 